\title{
Corpos em trânsito
}

\section{These bodies in transit}

DOI: http://dx.doi.org/10.5965/198431781642020264

\author{
Anamaria Fernandes Viana \\ Universidade Federal de Minas Gerais - UFMG \\ anamariafernandes160@gmail.com | ORCID | LATTES
}

\begin{abstract}
RESUMO
Este relato traz uma reflexão sobre uma experiência de dança junto a um grupo de mulheres acolhidas no Setor Psicológico da Penitenciária de Mulheres da cidade de Rennes, França e algumas profissionais da saúde daquele espaço. Esta experiência foi vivenciada pela autora, que ali esteve ministrando aulas no ano de 2018. O texto é nutrido de reflexões e anotações tiradas de um caderno de bordo que a acompanhou durante este percurso. Nele encontra-se a trajetória da construção de um espaço comum, moldado por esses corpos em trânsito. $O$ texto aponta as hesitações, descobertas, surpresas, questionamentos e adversidades dessa experiência; discute também alguns dos problemas encontrados dentro da unidade e suas respectivas tensões; e, de forma cronológica, propõe ao leitor o compartilhamento desta experiência, tendo como resultado a transformação daquelas mulheres que, aos poucos, foram se desfazendo de algumas amarras, carapaças, proteções para se entregarem ao movimento dançante. O principal objetivo é reafirmar não só a potência de práticas artísticas em contextos sociais inabituais como também a importância de sua aplicabilidade.
\end{abstract}

Palavras-chave: Presídio; Arte; Experiência;

\begin{abstract}
This report reflects on a dance experience with a group of women welcomed in the Women's Penance Psychological Sector of the city of Rennes, France and some health professionals from that space. This experience was lived and taught by the author in the year 2018. The text is nourished by reflections and notes taken from a logbook that accompanied her during this journey. In it is the trajectory of the construction of a common space, shaped by these bodies in transit. The text points to the hesitations, discoveries, surprises, questions and adversities of this experience. It also discusses the problems encountered within the unit and their respective tensions. In a chronological way, it proposes to the reader to share this experience that results in the transformation of those women who, gradually, were undoing some bonds, shells, protections to surrender to the dancing movement. It aims to reaffirm not only the potency of artistic practices in unusual social contexts, but also the importance of their applicability.
\end{abstract}

Keywords: Prison; Art; Experience; 


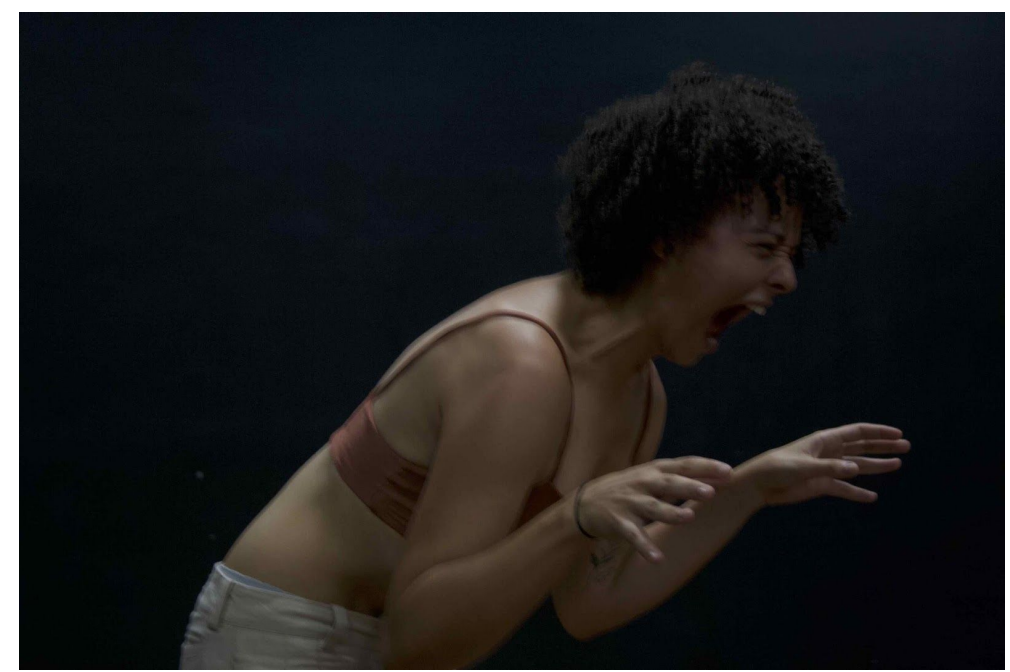

Figura 1: Fotografia do espetáculo Outras de nós. Cia Ananda. Direção: Anamaria Fernandes Viana. Na foto a dançarina Beatriz Nobel. Acervo: Cia Ananda. Direitos de utilização cedidos.

Toda opressão cria um estado de guerra.

Simone de Beauvoir ${ }^{1}$

Este texto foi escrito em três tempos e envolve diferentes espaços.

O ponto de partida e ponto central para as reflexões é um diário de bordo que me acompanhou durante um trabalho de dança junto a mulheres em situação de cárcere, em junho e outubro de 2018. Estas mulheres estavam sendo acolhidas pelo Setor Psicológico da Penitenciária de Mulheres de Rennes, França, que me havia convidado.

No primeiro momento da escrita, os espaços que meu corpo atravessava se dividiam entre a prisão e esta cidade que me acolheu durante 20 anos da minha vida. Era para mim vertiginoso a passagem de um espaço para o outro. Este momento em que se deixa para trás um lugar, com seu ritmo e suas regras e que se adentra em um outro, tão diferente. E, no entanto, eram dois lugares situados, em certo sentido, num mesmo lugar.

\footnotetext{
${ }^{1}$ DE BEAUVOIR, 2014.
} 
Com o tempo e a vida, fui percebendo que as nuances entre dois ambientes como aqueles podem ser bem maiores do que parecem; e que, entre o preto e o branco, existem muitas cores. Esta experiência me mostrou, entre outras coisas, que algumas vezes a liberdade pode ser vivenciada atrás das grades, assim como a prisão pode estar do lado de fora. Lembrando Novaes, "O homem só é livre, pois, não pela vontade, mas quando entra de posse de sua potência de agir" (NOVAES, 2002, p. 13).

O segundo momento da escrita foi aquele em que revisitei minhas anotações, para mergulhar novamente nas memórias ainda latentes no meu corpo. Já estava no Brasil e tinha, a partir de um material produzido por aquelas mulheres - áudios e escritos - iniciado um processo de criação com outro grupo, também de mulheres, que culminou em um videodança ${ }^{2}$ e uma peça coreográfica ${ }^{3}$. Neste momento, também me voltei para a escrita de um possível artigo.

Esta experiência, vivenciada por todos/as nós, ao ver uma foto antiga, ao escutar uma música que traz recordações de outrora, é uma experiência corporal que envolve o tempo e o espaço. É como se o tempo fizesse uma pausa. Um silêncio. Como se viajássemos sem sair do lugar. Na bagagem de mão, trago comigo o que ficou, os restos, as marcas, os traços. Mas este meu corpo que faz este passeio já não é o mesmo. É um corpo que atravessou outras paisagens, que se nutriu de outros encontros, que mergulhou em si mesmo e se deslocou.

O último momento, no qual eu me encontro, é aquele compartilhado por muitas outras pessoas, e em várias partes do mundo. O confinamento. Há mais de três meses não saio de minha casa e vivencio, pela primeira vez em minha vida, a experiência da reclusão. Mesmo que de maneira extremamente diferente daquelas mulheres, esta experiência me traz uma percepção de corpo, de tempo e espaço totalmente inéditas. E me faz encontrar novamente e ao mesmo tempo de maneira diferente aquelas mulheres, que continuam tão distantes e simultaneamente tão próximas de mim.

\footnotetext{
${ }^{2}$ Link videodança $\grave{A}$ travers: https://www.youtube.com/watch?v=H5CDnITIZ2s\&feature=youtu.be

${ }^{3}$ Link espetáculo Outras de nós: http://ciaananda.com.br/criacoes/outras-de-nos/
} 
Essas "diferentes vozes" (do caderno de campo, das reflexões à época e atuais), diferentes temporalidades colocadas, espaços e experiências de corpo estão presentes nas linhas que escrevo e proponho compartilhar.

Longas penas. Algumas mulheres que encontro estão naquele espaço há mais de 10 anos, com alguns anos ainda a cumprir; outras esperam também há anos para ser julgadas. Todas vivenciando um espaço de completa exclusão social, e, consequentemente de estigmatização. A maioria dentre elas, assim como a maioria das mulheres em situação de cárcere naquele país, vive uma situação caracterizada por "discriminação geográfica"4. Ou seja, além das grades que as separam da sociedade, estão distantes geograficamente de seus entes queridos. Algumas das que encontrei só veem seus filhos uma vez ao ano; outras, menos ainda.

Sabemos que grande parte das mulheres em situação de cárcere foram vítimas de violência de forma direta ou indireta por parte dos homens e que a violência contra as mulheres não é vinculada apenas ao meio ambiente, território, geração, nacionalidade ou religião. Ela permeia todos esses espaços e é tributária de uma sociedade desigual, na qual as relações de dominação e poder ainda são predominantes e constituem o controle social de homens sobre as mulheres. $E$ isso não é de hoje. Este modo de fazer é histórico mesmo se, nos tempos de outrora, a noção de violência contra as mulheres não era vista como um problema social. Como nos lembra Bourdieu (2007), o que hoje chamamos de violência, ontem era denominado de "educação", com o objetivo de "disciplinar" as mulheres para que, assim, respeitassem os seus homens, fossem eles maridos, pais ou outros. Este modo disciplinatório era orquestrado, por assim dizer, por três entidades principais: a família, a igreja e a escola (BOURDIEU, 2007, p.103). Mas podemos dizer que, infelizmente, há ainda uma certa naturalização da violência enquanto um destino traçado para as mulheres.

\footnotetext{
${ }^{4}$ Termo concebido por François Bes, coordenador de uma unidade penitenciária na França. A discriminação geográfica se dá pelo fato de todas as prisões femininas estarem localizadas em uma parte do norte do País.
} 
A violência contra as mulheres durante o período de confinamento, no momento em que escrevo estas linhas, aumentou em $50 \%$. Não irei nesse breve artigo me delongar sobre estas questões, pois não é meu objeto de reflexão. Mas pareceu-me indispensável ao menos evocá-las.

Proponho ao leitor um mergulho nas águas de uma experiência artística em um lugar não comum. Uma experiência coletiva e ao mesmo tempo vivenciada, como qualquer experiência, de maneira única, por cada uma de nós. Uma experiência transformadora. A esse respeito, cito Larossa:

De fato, na experiência, o sujeito faz a experiência de algo, mas, sobretudo, faz a experiência de sua própria transformação. Daí que a experiência me forma e me transforma. Daí a relação constitutiva entre a ideia de experiência e a ideia de formação. Daí que o resultado da experiência seja a formação ou a transformação do sujeito da experiência. Daí que o sujeito da experiência não seja o sujeito do saber, ou o sujeito do poder, ou o sujeito do querer, senão o sujeito da formação e da transformação. (LAROSSA, 2011, p.07)

Sobre as mulheres que iria encontrar, nada sabia.

Já tinha dançado duas vezes naquela prisão, mas agora era minha primeira oportunidade de propor uma oficina e de realmente encontrá-las. Algo que desejava há muito tempo.

O grupo era também composto por algumas profissionais da saúde daquele espaço.

Como narrar, em poucas linhas, a extensão daquela experiência?

No início, muita curiosidade da minha parte... As perguntas borbulhavam.

O que tinham feito para estar lá?

Quais crimes haviam cometido?

Mas fui aos poucos deixando esta curiosidade do passado se transformar em curiosidade do presente.

Estar com elas e nada mais. Encontra-las sem pré-requisitos, sem histórico, sem medo. Deixar-me contaminar por este presente, pelo devir de cada uma. Proporcionar um espaço de afeto, de afetação, de contágio. De gota em gota para chegar ao mar, pois 
cada variação, por minúscula que seja, ao propagar-se e ser imitada torna-se quantidade social e assim pode ensejar outras invenções e novas imitações, novas associações e novas formas de cooperação. Nessa economia afetiva, a subjetividade não é efeito de superestrutura etérea, mais força viva, quantidade social, potência psíquica e política (PERBALT, 2003, p.23).

Pouco soube sobre elas. Somente o que vinham me contar, de forma individual e espontânea. Como o caso de uma delas cujo perfil era o mais comum: de classe baixa, negra e vítima de violência conjugal. Poucas semanas após o nosso workshop, ela iria dormir com suas filhas por uma noite, depois de quatro anos de espera. Me disse um dia que ali, atrás de tantos muros e grades, tinha enfim encontrado um espaço de liberdade. Como nos diz Novaes:

O homem ao estar no mundo está sujeito a determinações exteriores: assim muitas vezes ele não realiza a condição natural e humana de sua potência (que é ser livre) para se deixar dominar, torna-se servo. (NOVAES, 2002, p. 8).

O workshop se intitulava "História de Mãos" e foi feito em duas etapas - junho e outubro de 2018.

Neste texto, procuro relatar alguns momentos desse encontro transcritos no meu pequeno diário de bordo, revisitados, como já dizia, em outros momentos e espaços. Mesmo depois de quase dois anos, posso dizer que esta experiência foi um atravessamento visceral que me tocou e me toca, ainda hoje, profundamente.

Ao término do último dia de trabalho, iniciei a escrita no meu diário com essas perguntas: O que dizer? Como transcrever todas essas emoções latentes palpáveis no meu corpo? Como colocar em palavras essa tempestade de emoções que me atravessa?

Mas dentro do que me é possível fazer, tentarei colocar de algum modo as reflexões e a riqueza que esta experiência me trouxe e que podem - quem sabe? inspirar outras experiências neste lugar sensível que é o da arte, especialmente quando vinculada à vida. 
$\mathrm{Na}$ abertura do caderno verde que me acompanhou nessa trajetória, encontro uma folha de árvore, na qual uma participante escreveu ao fim de nosso encontro: obrigada por este excelente momento!

Mas para chegar àquele momento percorremos uma longa estrada.

Primeiro, um planejamento de quase três anos com uma psicóloga do serviço.

E muitas reuniões com profissionais da prisão: médicos, psicólogos, enfermeiros, chefes.

E depois, muitos outros obstáculos:

Autorizações, documentos, interdições, controle de raio $\mathrm{x}$, protocolos, guardas, portas, chaves, mais portas, mais chaves... Esperas entre uma porta e outra, câmeras de segurança, uniformes, muralhas de pedra, interfones, novas esperas, outras chaves...

Dentro da prisão, um jardim. Um jardim grande e lindo, mas proibido para as prisioneiras. Dali eu podia ver roupas dependuradas nas grades.

Ao adentrar no espaço no qual a oficina iria acontecer, outras paredes, outras muralhas. Invisíveis, mas presentes, entre umas e outras.

$\mathrm{Na}$ oficina, só mulheres. Umas livres, outras não. Entre as livres estavam psicólogas, psiquiatras, fisioterapeutas e eu.

Nos apresentamos umas às outras:

As livres, com suas profissões e seus sobrenomes.

Madame de Tal, psiquiatra. Mademoiselle de Tal, psicóloga.

As outras tinham só o sobrenome. E foi assim que se apresentaram:

Madame Lamounier.

A imagem que tenho deste primeiro dia é de um fluxo contínuo, como a água de um riacho. $\mathrm{E}$ o rumo deste riacho eu não conhecia. Nadava às cegas, tateava...

Trazia muitos desejos, é claro, mas o que tirar do bolso, o que abrir, qual fio puxar?

Tentava seguir os passos que me eram oferecidos em cada momento presente.

Estar junto. 
Lanço então uma proposta no ar, vejo se elas a seguram ou se a deixam cair no chão.

Pensava trabalhar basicamente com a improvisação, criação, gestos autorais. Mas logo percebi que não daria certo começar por ali.

Resolvi iniciar abrindo outras janelas: a dança brasileira e o yoga. Proponho uma ciranda, alguns deslocamentos lúdicos, um pouco de respiração.

Assim, meio que brincando, cada uma trabalhou a escuta de si, a do outro, a do grupo.

E vi, então, que uma primeira fresta se abria.

No meio das outras está Gwendoline.

Ela abre suas mãos trêmulas.

Tem a cabeça raspada e cicatrizes num braço.

Cortes. Muitos cortes.

Cortes da vida.

Suas mãos se abrem

De forma tímida e única

$\mathrm{O}$ gesto é pequeno

Mas com ele, ela parece abrir o mundo.

Respiramos a fragilidade, dançamos com ela.

O efêmero e o profundo.

É como me lembro deste momento.

Patrícia me dá seu sorriso e com ele abre um espaço, o do acolhimento. Sou acolhida por ela e já não me sinto tão estrangeira àquele grupo. Minha percepção do ambiente muda no acolhimento do seu olhar. Como se a cumplicidade silenciosa que sentia entre nós duas pudesse fincar meus pés naquele instante, com menos apreensão do momento por vir. Ela me fala que é cigana, tem cabelos cumpridos e lisos, teve um AVC na prisão. É a mais velha do grupo. Às vezes me olha como uma mãe, outras como uma filha. Um encontro.

O chão de madeira da sala na qual dançamos está sujo, muito sujo. Peço para tirar os sapatos, meias e pés ficam pretos. 
No dia seguinte, aquele fluxo contínuo que senti na oficina anterior se torna um vendaval. Foi o dia da chegada da Sônia.

Estávamos juntas esperando a última porta dentre as tantas portas se abrir quando ela me disse que o que ela mais amava no mundo era dançar.

Que tipo de dança?

Qualquer tipo, me responde.

Eu começo esta oficina com uma massagem de pés com uma bola de tênis.

Como? Isso é dança?

Sônia faz muitos comentários, recusa-se a participar e me transtorna.

O chão ainda está sujo, ela se recusa a tirar os sapatos, Amel também.

No meu caderno escrevo:

Sônia; não mostra interesse pela oficina. Eu não consegui manter nenhuma proposta. Ela inundou o espaço com uma atmosfera tensa, quase desagradável - pelo menos para mim.

As propostas que fiz não tiveram duração - eu lanço uma proposição, o que foi lançado fica alguns instantes no ar e cai. Uma queda. Um estrondo.

Paf puf!

Amel se junta a Sonia. Eles conversam fora do grupo.

Eu não consigo me atentar ao grupo, ouvir os caminhos que as outras podem me levar....

Eu remo...

Eu remo contra a correnteza.

O tempo passa muito devagarrrrrrrrr

Espero que ela não volte amanhã.

Quarto dia - Chego antes para limpar a grande sala. Quando as participantes chegam e me veem com o rodo na mão se surpreendem. Sinto que de uma certa forma ficam tocadas pelo meu gesto. Comentam entre elas.

Pés descalços.

Sônia está de volta. Eu não entendo. Ela visivelmente não gostou - então porque ela está lá? Sinto uma espécie de suor dentro de mim, nos meus ossos. Como eu vou fazer? Qual caminho tomar? Qual porta abrir? Me sinto presa dentro dos meus limites, da minha incapacidade em lidar com a situação. Socorro!!!

No meu caderno: 
Procuro uma abertura primeiro dentro de mim depois no grupo procuro uma brecha para construir um começo de ponte uma relação.

Como criar esse link com uma pessoa que aparentemente não o procura, não o deseja.

Então, para quem? Para quê? Por quê?

Mas se ela não quer criar laço, não gosta do que proponho, por que ela ainda está aqui?

Procuro abrir espaços

Me deparo com muros

Muros de pedra

Acolher na dificuldade

Sobretudo minha dificuldade

aceitar que seus desejos não sejam os meus - aceitar realmente, profundamente e não superficialmente.

$\mathrm{E}$ o grupo. Sinto que presto menos atenção aos outros por essa preocupação permanente: Sônia.

Como criar um espaço comum neste contexto?

As discussões entre Sonia, Amel e agora Patricia parecem dificultar a concentração do grupo.

Eu digo às outras para voltarem a escuta para dentro de si.

Essas palavras e o pouco da atenção que dou a elas parecem abrir um espaço de disponibilidade, de presença - são dois grupos num mesmo espaço e eu, meio que sem rumo, navegando entre eles.

Terminamos a oficina com uma conversa. Digo então à Sônia que as discussões paralelas podem existir, mas muito discretamente, porque isso perturba a concentração do grupo e especialmente a minha. Sinto que preciso me posicionar, marcar a natureza daquele espaço que me propunha a construir com elas.

Ela parece escutar. Fala da sua dificuldade de ficar parada, que precisa de ação.

Quinto dia

Quando chego para limpar a sala. Inés já está passando o pano de chão.

No meu caderno: 
$\mathrm{Na}$ organização da minha oficina sinto que Sônia tornou-se o tema, o ponto nodal desta oficina. Minhas propostas são feitas em grande parte em função dela.

Novamente presente, meu corpo mais uma vez gela.

Mas algo parece ter mudado, Sônia desta vez parece estar realmente presente. Disponível. Ela me surpreende.

Já podemos colocar nossos pés em outras estradas, sinto que podemos viajar.

Lanço uma proposta de deslocamento livre com o olhar: podemos desviar o olhar de uma pessoa ou manter o olhar. Quando uma dupla faz a escolha de mantê-los, se aproximam, fecham os olhos e de lá surge uma pequena dança.

Meus olhos se encontram com os olhos da Sônia. Os fechamos para uma dança juntas, improvisada, em contato. Ela solta o peso de suas mãos, de seus braços nos meus. Ela se abandona e me oferece esse abandono.

Uma dança de um instante que parece mover o mundo. É enorme. Me sinto com um mundo nas mãos. Quase não sei o que fazer desta entrega. Nos separamos.

Pouco depois ela pede para sair da sala. Uma oração a espera, algo urgente. Talvez um demais, um transbordamento. Ela precisa sair, imperativamente.

Depois daquele dia e durante essa primeira etapa do workshop, Sônia se colocou quase sempre no centro.

No centro do espaço, da roda, das atenções, da minha atenção.

Ela se tornou minha assistente, ao ponto de às vezes corrigir os outros. Ela colocava seus pertences perto dos meus. Escolhia suas músicas para dançar nos momentos de pausa. Dançava para ela, para mim, para nós.

O grupo é constituído aos poucos. Gwendoline, Gwenola, Patricia, Solene, Nathalie, Eva, Justine, Inês, Honorine, Gratiela, Amel, Sthephanie, Marie Cristine, Laila, Annabelle. Trocas de olhares, uma confiança que é tecida nesses passos de dança, nessa dança de tentativas, nas palavras, na mão que pega uma outra, que se deixa conduzir.

As profissionais já têm nomes e não sobrenomes. Elas participam das propostas da mesma forma que o resto do grupo, com seus corpos. Tocamo-nos, cantamos, dançamos, estamos juntas. Vulnerabilidade e fragilidade expostas à vista de todos/as, pertencentes a cada uma de nós, no espaço que ocupamos, que construímos, que transformamos. 
Não existe mais presidiaria, médica ou professora.

Somos mulheres compartilhando um momento, uma dança de encontros, ou de tentativas de encontros.

Chega um dia Chrystel, atriz a quem pedi para se juntar a mim neste projeto.

Chrystel chega devagar, de mansinho, com a delicadeza que ela tem e ganha a confiança do grupo e da Sônia que até então só queria dançar comigo. Me sinto mais livre para caminhar pelo grupo e sinto que Sônia finalmente faz parte dele, do jeito dela ...

Inés traz a generosidade do estar junto, colore aquele espaço com a bela energia de estar com.

Ela me diz que encontrou sua liberdade naquele lugar.

Emagreceu 20 quilos, cuida dela pela primeira vez na vida.

Aprendeu a se conhecer.

Tem duas filhas pequenas que moram longe, com o pai.

Ela é luminosa, leve e alegre.

Mulher negra, olhos grandes, sorriso nos lábios.

Adora fazer massagens mas pede para não ser tocada.

Não percebe que é também tocada ao tocar.

No dia seguinte, ela traz Gratiella. Uma mulher alta, negra e bonita que parece vir naquele dia meio que recuando, puxada pela amiga.

Gratiella participa timidamente das propostas. Entra dando pequenos passos... observando...

Amel, desde o primeiro dia mantém seus óculos escuros. Durante uma de nossas reuniões após uma oficina, uma profissional diz que pode ser uma maneira de se proteger, de manter distância. Procura dar uma explicação a essa escolha. Uma explicação que analisa. Escuto e penso - talvez sim, mas talvez não ...

A primeira semana de trabalho termina.

No final de semana Chrystel me mostra um pequeno poema de Jean Rousselot que me toca

O caramujo é lento, mas nunca chega atrasado ... 
o poema termina assim:

"Não é recomendado empurrar um rio nas costas para que ele corra mais rápido

O rio está fazendo o melhor possível."

... sim, fazemos o que damos conta e é só aceitando os limites desse "nosso melhor possível" que os elos podem ser tecidos, que o encontro pode acontecer.

As mulheres me acompanham fora da prisão neste fim de semana. Eu falo sobre elas com as pessoas que encontro. Me sinto tocada, extremamente tocada. Pauline, uma amiga musicista me escuta e quer se juntar a nós. Ela convida sua irmã Elsa, também musicista. Elas estarão conosco na próxima terça.

No início do projeto, havia uma ideia: fazer um vídeo-dança a partir de histórias dançadas com as mãos. O projeto de vídeo é abandonado a saber que seríamos obrigadas a deixar o cartão de memória da câmera para a visualização das imagens pela administração penitenciaria. A oficina, assim como as sessões terapêuticas, são espaços de liberdade de expressão que não devem ser violados.

Em todo lugar olhos, vigias, intrusão do espaço pessoal.

Isso não poderia acontecer também naquela oficina.

Discutindo com as profissionais, uma outra ideia aparece: E se gravássemos as vozes dessas mulheres para que elas pudessem servir de base para uma criação no Brasil?

Tinha no Brasil o projeto de iniciar uma criação com dançarinas em torno do feminino ${ }^{5}$. Tínhamos feito algumas reuniões e deveríamos começar o trabalho depois da minha volta da França.

Apresentei então esse projeto ao grupo. Quase todas ficaram encantadas. Mas não todas, uma participante preferiu não aderir.

Como não havia obrigação de participar deste projeto para continuar fazendo parte das oficinas, mantivemos a ideia.

Começamos então a aventura da escrita.

\footnotetext{
${ }^{5} \mathrm{O}$ trabalho em questão foi realizado na Cia. Ananda. Projeto de extensão da UFMG, coordenado pela autora.
} 
Eu queria tocar a criatividade daquelas mulheres - deixar viajar a imaginação

Mas tudo parecia tão compacto, sem brechas para a invenção.

Às vezes duro como concreto, como os muros que nos cercavam.

Aos poucos, por meio de propostas lúdicas, as palavras e frases começaram a surgir.

\section{Dentre elas}

Eu sacudo, como se quisesse fazer tremer a terra.

Eu bato fortemente na mesa, como se ela pudesse escutar os meus gritos.

Eu quero andar como se eu fosse livre.

Eu grito como se estivesse frente ao mar.

Nós corremos como se estivéssemos sendo perseguidas.

Eu como tijolos.

Você respira como se fosse uma janela.

Nós galopamos como se nossas vidas dependessem disso.

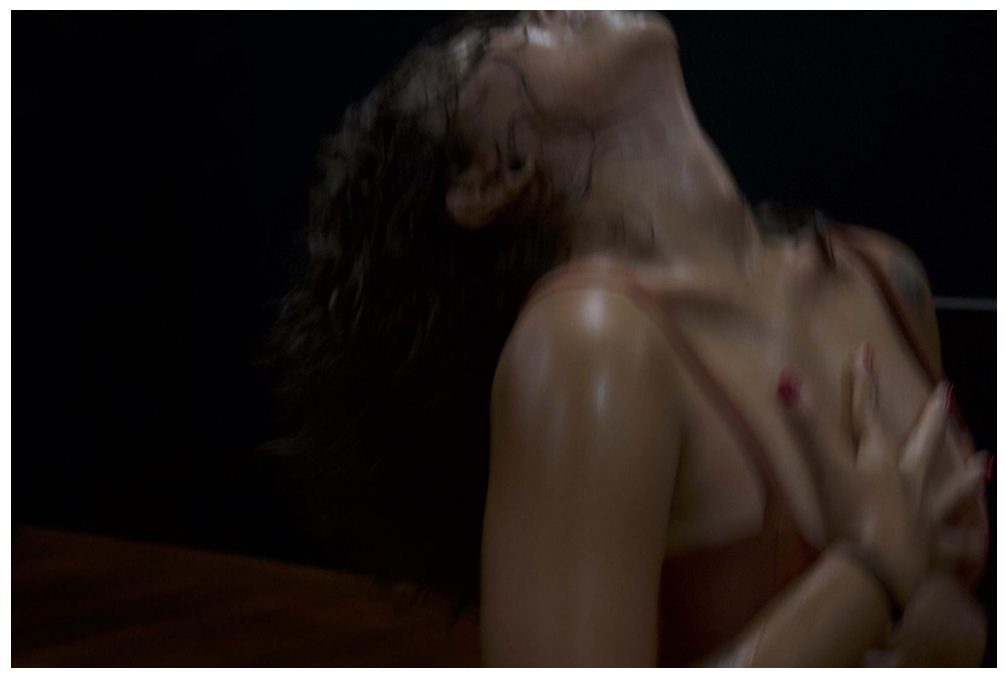

Figura 2: Fotografia do espetáculo Outras de nós. Cia Ananda, 2020. Direção: Anamaria Fernandes Viana. Na foto a dançarina Duna Dias Viana. Acervo: Cia Ananda. Direitos de utilização cedidos.

No meu caderno:

Gwendoline entra na escrita.

Um mergulho delicado, ela parece viajar entre palavras.

Cria espaços, as brechas vão surgindo.

Ela parece fazer surgir o som entre as palavras, os espaços entre. 
Nós dançamos as frases escritas. A confiança parece crescer a cada oficina.

Corremos e gritamos, nossas vozes perfuram agora as paredes, voamos através das paredes.

Respiramos, dilatamos nossos pulmões.

No final de cada oficina um momento de profundo relaxamento.

Isso não é possível para a Sônia.

Mas não importa,

o caramujo nunca está atrasado

ele tem seu próprio tempo.

Um dia peço à Amel que tirasse os óculos para este momento de relaxamento. Ela os levantou e me mostrou uma grande verruga em sua pálpebra. Ela não queria ser vista assim.

Recebo suas palavras como um presente! Ela nos faz avançar, nos mostra como podemos nos trancar com nossas interpretações. Enquanto observador, muitas vezes acredito que o que vejo é a verdade. Mas o que vejo, vejo com meus olhos, através das lentes da minha experiência, dos meus limites, das minhas emoções. Coexistem então muitas verdades num mesmo espaço tempo. Amel nos ensina o quanto temos a ganhar com esse silêncio interior. Nos convida a abandonar nossas verdades absolutas, verdades ancoradas em postulados, em dogmas. Nos incita a trilhar um caminho da escuta, de não querer ou falar no lugar do outro, pelo outro. Coisas aparentemente tão simples, mas que na verdade são tão difíceis de serem colocadas em prática. O silêncio dos nossos julgamentos, dos nossos preconceitos, desencadeia, a cada momento, no nosso olhar sobre o outro, na nossa relação com o outro. Este silêncio, quando conquistado, abre espaços, abre uma possibilidade outra de escuta, de contato, de presença, do devir.

O workshop continua, tem sua identidade, criada por esse grupo, por essas mulheres.

Algumas passam por ele sem ficar - outras estão lá todos os dias. Nós improvisamos ao som do clarinete e da flauta com as musicistas. Cantamos uma música brasileira.

Cada uma põe um pouco de sua especiaria, do seu tempero, da sua cor, às vezes da sua dor... Também choramos juntas. Estamos juntas.

Inés traz um dia alguns cockies feitos por ela. Um deleite. 
Um momento delicado. Compartilhado. Comemos, conversamos, nos entregamos. Às vezes as paredes parecem não estarem mais lá. Às vezes sinto que estamos em outro lugar ou em lugar algum. Um lugar sem nome. Livres entre esses muros, livres atrás das portas fechadas.

No dia seguinte Inés trabalha e não está conosco. Assim como muitas outras ela costura uniformes para os guardas da prisão. Ela não gosta, mas o trabalho the dá um pouco de dinheiro.

Gratiella então vem sozinha. Ela não é mais puxada pela amiga. Ela chega antes e limpa a sala. Ela toma a palavra pela primeira vez no grupo. Me fala que tem um filho autista, que morava na Holanda e que seus 5 filhos estão com a irmã.

Ela fala pouco francês.

Patrícia, mesmo em estado de saúde frágil, está sempre presente. Ela tem também uma generosidade de presença que me toca. Aquele dia foi o último em que a veria. Eu não sabia disso ...

Chega no último encontro desta primeira etapa do workshop.

Um vínculo foi tecido entre as pessoas. Juntas criamos um território de liberdade, de prazer, de abandonos, acredito que também de transformação.

Neste dia, dançamos com novelos de lã. Um novo espaço nascia pelos caminhos deixados no chão. Uma teia de aranha, colorida, entrelaçada pelas trajetórias de cada uma. Num espaço desta teia, está Sônia, que faz, com os fios, uma imagem abstrata que se mistura a um coração.

Contamos histórias, compartilhamos cada momento com a energia de cada uma. O gravador está preparado. As palavras, as frases são entregues. Elas viajarão até o Brasil.

$\mathrm{O}$ eco deste encontro ressoa fortemente em mim. No que vejo, no que vivo. As palavras chegam até as dançarinas brasileiras, em seus corpos, em suas danças, as atravessam, atravessam também suas histórias de vida. Um vídeo-dança é criado e tem como nome À travers. 


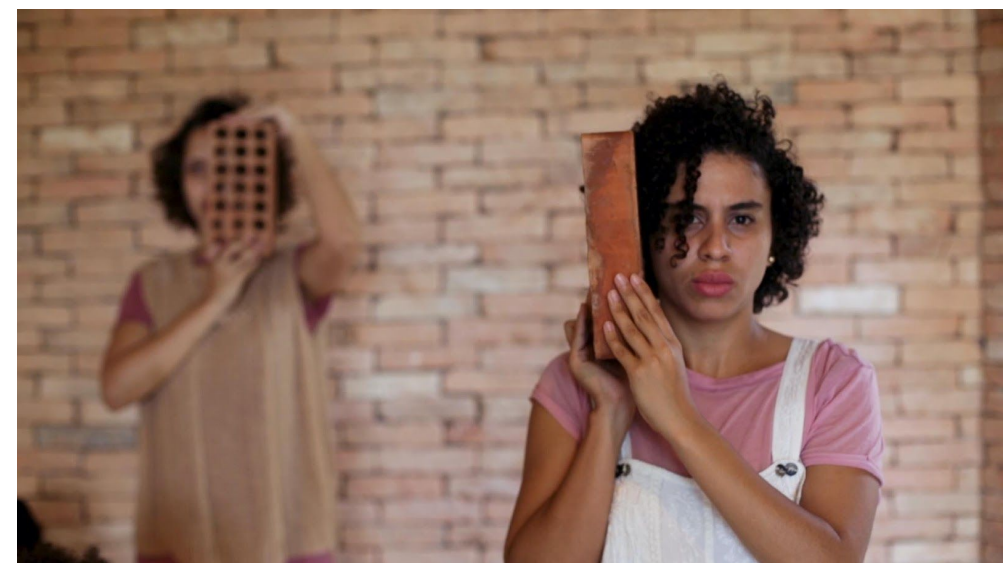

Figura 3: Fotografia do videodança À travers. Cia Ananda, 2019. Direção: Anamaria Fernandes Viana e Carla Normagna. Na foto as dançarinas Joicinele Alves Pinheiro e Duna Dias. Acervo: Cia Ananda. Direitos de utilização cedidos.

Chega outubro. De volta.

Sônia se joga em meus braços. Nos jogamos nos braços umas das outras. Inés, Gratiella, Nathalie, Justine, Lailá e outras novas participantes. Para este primeiro dia venho com outros 5 dançarinos brasileiros. Dentre eles Gustavo, que é também músico, Oscar que é dançarino, ator e pessoa com deficiência visual e Duna que participou da criação feita no Brasil.

Música, cantos, dança. Muita entrega e alegria de estar juntos. Sônia fica intrigada e impressionada com Oscar que dança no centro da roda. Ele é cego e dança. Incrível! Como ele consegue? Ela se mostra tocada por sua dança, por suas capacidades.

Assistimos o vídeo feito no Brasil com as dançarinas da companhia Ananda.

Compartilhamos estes diferentes momentos de pura felicidade. Forte. Potente para todos e todas.

No jardim central da prisão, de onde vemos as janelas das células, escutamos suas vozes se despedindo de nós. Au revoir! À demain! Merci!

Saímos com lágrimas nos olhos.

Eu deveria retomar o trabalho na segunda-feira seguinte.

No domingo, resultado das eleições presidenciais no Brasil.

Um tsunami. 
Nesta segunda-feira só conseguia chorar, incapaz de trabalhar, de me mexer, de me levantar. Nocaute.

Como oferecer nestas condições? Como estar junto?

Este trabalho pede um certo estado de presença.

Impossível me colocar no meio do caminho.

No dia seguinte, sou recebida por essas mulheres.

Elas me trazem de volta à vida, me colocam em pé, de pé.

Me sinto sustentada por elas.

Gratiella me canta uma música da sua terra, algum país da África. Cantando, faz o gesto de remar com seus braços. Canta numa língua que nunca ouvi.

Me diz depois que cantava pedindo que mantivesse minha força.

Que minha mãe terra sempre estará lá, no meu corpo. Que das cinzas nasciam flores.

Gratiella está com câncer. Ela me levantou, me deu força para acreditar e ter esperança. Esperança no ser humano.

Tenho a impressão de que este momento em que não estivemos juntas- entre junho e outubro - não foi uma pausa do trabalho iniciado.

Sinto que continuamos a trilhar este caminho que abrimos juntas.

Cada uma, do seu ponto de partida avançou. Passos de caramujo, de caracóis, um bater de asas...

A confiança e disponibilidade são ainda mais fortes, dando lugar ao abandono. Corpos que se tornam poesia. A poética de estarmos juntas e construir juntas.

Sônia parece outra. Ela oferece o espaço, abre espaços, cria espaços, ela está com as outras. Gratiella nos dá o presente de uma dança com Chrystel. Ela improvisa. Elas improvisam. No final deste duo se deita no chão. Completamente abandonada, ela é puxada pelos pés, mãos, braços no chão, mãos que a tocam, corpos que rolam uns nos outros. Abandono.

Um dia Pauline e Elsa trazem instrumentos de batucada brasileira. Tocamos tambores, tamborins, agogôs, dançamos, cantamos. 
Inés dança no centro do círculo. Sua dança é potente. Ela dança e canta, olhando cada uma de nós, uma por uma, nos oferecendo uma energia maravilhosa que nos contamina. Parece tirar alegria do chão aonde pisa.

É o último dia. Meu coração está apertado. Choro por dentro. Choro por fora.

Sinto que encontrei cada uma delas. Fui tocada pela poética única de cada pessoa que conheci.

Convido minha mãe a se juntar a nós para uma pequena oficina de flores de papel de seda. Queria que tivessem uma lembrança para levarem para as células.

E queria também tentar levantar minha mãe que desde o resultado das eleições estava em depressão.

Flores de seda.

Uma pequena lembrança desta fragilidade efêmera, tão linda.

Minha mãe é acolhida com muito carinho e com muita alegria.

Chora nos braços de uma delas.

Gwendolina está novamente conosco. Não pôde participar até então porque estava fazendo uma formação. Seus cabelos cresceram. As cicatrizes no braço parecem não serem mais tão dolorosas.

Outras mulheres vieram pela primeira vez naquele dia. Criamos um espaço de confiança tal que as novas participantes se entregaram sem dificuldades às propostas dançantes.

As carapaças parecem ter caído, feixes de luz furaram as paredes.

As muralhas desabaram.

Porosidade no ar.

O corpo poroso.

O desejo de compartilhar o imprevisível, o inesperado, a generosidade de cada uma. Improvisamos. Improvisamos.

Escutamos mensagens áudio enviadas pelas dançarinas do Brasil. As mulheres se dizem profundamente tocadas.

O gravador está novamente lá, para captar as palavras deste último momento. Gratiella fala 
O respeito é a coisa mais importante do mundo. Não despreze as pessoas.

Eu perdi minha avó há mais de 21 anos, não sei onde ela está, mas ela sempre me provocava ... Gratiella, você não é melhor que ninguém e ninguém é melhor que você. $O$ respeito é a coisa mais importante na vida, você dá, você recebe, você não dá, você não tem respeito.

É assim...

Não estou julgando ninguém, eu não saí daqui.

Mas temos que aprender a perdoar nossos pecados e seguir em frente.

Porque aqui não é o paraíso.

Mas, tente se perdoar. Se você não pode se perdoar, ninguém pode ajudá-lo.

E não deixe ninguém falar de você, não deixe ninguém te derrubar, Seja você mesma e ame a si mesma.

E então, veio o momento do silêncio, o momento de ser pega nos braços umas das outras para se dizer adeus. Um profundo silêncio compartilhado.

De volta ao momento presente, longe de braços e abraços, me sinto conectada com muitos. Uma conexão outra, neste espaço outro que hoje compartilhamos.

A experiência na prisão me mostrou a importância da veracidade, da generosidade, do não julgamento, do estar junto, da humildade e do silêncio. Preciosidades que muitas vezes não praticamos no nosso dia-a-dia.

Hoje, individualmente e coletivamente, pagamos o preço do excesso da nossa ganância, arrogância, egoísmo, individualismo e ignorância.

Em uma entrevista recente ao jornal Estado de Minas, Ailton Krenak, líder indígena, ambientalista e escritor nos diz que "nos acostumamos com a ideia de que somos uma humanidade" e que "(..) ninguém mais presta atenção ao sentido do que venha mesmo ser humano" (KRENAK, 2020). E ele tem razão. Que possamos, com esta experiência, olhar para o outro com mais amor e menos ódio, acolher a diversidade, a pluralidade, as escolhas de cada um, de cada uma. Que possamos cuidar do nosso planeta e não devastá-lo, que possamos abraçar as árvores, para nos abraçarmos novamente. 
Somos seres relacionais. Talvez somente agora tenhamos a dimensão da importância do outro que me constitui, e que, assim como a natureza, é parte integralmente de mim mesma. Neste espaço relacional em que vivemos, transformamos e nos transformamos. Vivemos imersos numa rede dinâmica de relações, emoções, interações. Uma rede de afetos em constante movimento. E por isso, somos responsáveis por nossas escolhas cotidianas que, queiramos ou não, reverberam ao nosso redor. Somos responsáveis pela criação de espaços de liberdade assim como pelos espaços de opressão, pelo que criamos e também pelo que deixamos de criar. Pelo que destruímos e pelo que deixamos de acreditar. Somos responsáveis pelo nosso silêncio diante de injustiças, descriminações, desigualdades.

Que tenhamos a humildade de aprender com este grito da natureza, que tenhamos a sabedoria de aprender com aquelas pessoas catalogadas como inaptas, loucas, doentes, incapazes. Que pisemos com mais delicadeza sobre a terra. Que façamos um pouco de silêncio. Silêncio.

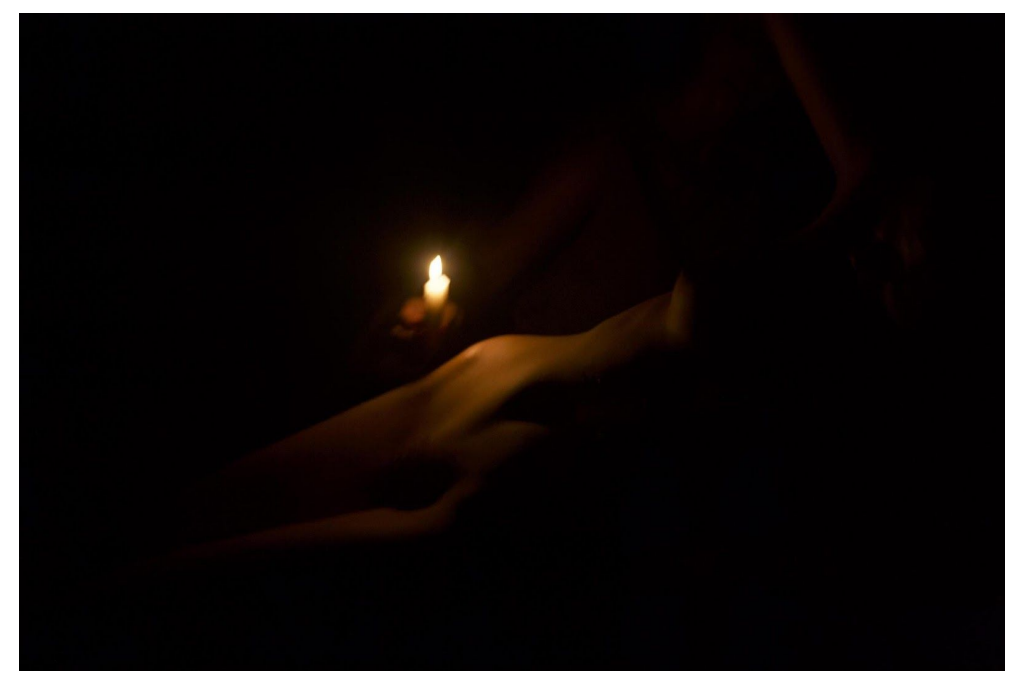

Figura 4: Fotografia do espetáculo Outras de nós. Cia Ananda, 2020. Direção: Anamaria Fernandes Viana. Na foto as dançarinas Beatriz Nobel e Duna Dias Viana. Acervo: Cia Ananda. Direitos de utilização cedidos.

\section{REFERÊNCIAS}

DE BEAUVOIR, Simone. O segundo sexo. Rio de Janeiro: Ed. Nova Fronteira, 2014. 
BOURDIEU, Pierre. A dominação masculina. 5. ed. Rio de Janeiro: Bertrand Brasil, 2007.

KRENAK, Ailton, entrevista. Jornal Estado de Minas. 03/04/2020. "O modo de funcionamento da humanidade entrou em crise", entrevista com Ailton Krenak. Disponível em:

https://www.em.com.br/app/noticia/pensar/2020/04/03/interna pensar,1135082/funcionamen to-da-humanidade-entrou-em-crise-opina-ailton-krenak.shtml. Acesso em 08/05/2020

LARROSA, Jorge. Experiência e alteridade em educação. Reflexão e Ação, v. 19, n. 2, p. 04-27, 2011.

NOVAES, Adauto. 0 avesso da liberdade. São Paulo: Cia das Letras, 2002.

PELBART, P. P. Vida capital: ensaios de biopolítica. São Paulo: lluminuras, 2003.

SANTOS, Thandara; VITTO PINTO de, Renato Campos. Levantamento Nacional de informações penitenciarias. INFOPEN Mulheres - jun. 2014. Disponível em:

https://www.justica.gov.br/news/estudo-traca-perfil-da-populacao-penitenciaria-feminina-no-b rasil/relatorio-infopen-mulheres.pdf. Acesso em 20/11/2020. 